\title{
On the relationality of centers, peripheries and interactional regimes
}

\section{Translanguaging in a community interpreting event}

\author{
Mike Baynham \& Jolana Hanušová \\ University of Leeds, England
}

In this paper we discuss a multilingual interactional event that involves both interpreting and literacy work, part of a large scale study on translanguaging in superdiverse urban settings. ${ }^{1}$ In the first part of the interaction, the center/periphery dynamic is played out in what might be called "contested translanguaging" between Standard Czech and a Slovak influenced dialect of Czech, in the second part in contested translanguaging between Standard Czech and English. The center/periphery dynamic, we argue can be understood in terms of attraction/repulsion. The translanguaging involves a struggle over both meaning and form in which some participants lose out. The second part of the interaction is a dramatic reverse in what is treated as central and dominant in the first part, suggesting a hierarchical ordering of interactional regimes. We will argue for the necessity of taking into account these hierarchically ordered interactional regimes and the linguistic ideologies associated with them in the shaping of translanguaging practices.

Keywords: center/periphery; translanguaging; community interepreting; interactional regimes; language ideologies

\section{Introduction}

Blommaert, Collins, and Slembrouck (2005) have argued that language use including multilingualism is shaped by polycentricity and interactional regimes. Perhaps less developed is the idea that the existence and meaning of centers is relational, that their existence as centers depends on the existence of peripheries. Each center

1. Translation and translanguaging: Investigating linguistic and cultural transformations in superdiverse wards in four UK cities (TLANG) AHRC funded (AH/L007096/1). Principal investigator Angela Creese 2014-2018. 
exists in relation to one or more peripheries and each periphery in relation to one or more centers. Moreover in the bumpy and sharply unequal global and local terrains of economic, political and cultural/semiotic power and influence, each center is not equally influential and attractive in the sense of attracting or drawing people and resources towards itself. (It is worth emphasizing at this point that centers can provoke not just attraction, but also repulsion.) Centers can be peripheral in relation to other centers. These relations of power, influence and attraction/ repulsion are of course played out in the interactional regimes that shape multilingual encounters, for example the one we examine in this paper.

\section{Center/periphery, periphery/center}

In a globalized world the notions of periphery and center or rather periphery/ center have been influential in disciplines as wide-ranging as political science, economics, sociology and anthropology, geography and planning as a way of capturing the imbalances and inequalities of power and resources. Associated with the dynamics of periphery/center are the dynamics of flows and the assumptions of inequality which direct flows from peripheries to centers. We are currently for example witnessing massive migration flows South/North towards European centers. Of course these center/periphery relations are not just a question of unequal concentrations of political power and economic resources, but can also be extended to understand cultural flows and the unequal distribution of cultural resources including language. So the notion of center/periphery has become important for that trend in sociolinguistics which seeks to understand the ways that large scale macro aspects of social order are reproduced or perhaps better produced in the small, scale interaction that is the focus of linguistics. Wang et al. write:

The center-periphery dynamics has received far too little attention from both linguistic and social scientists, while the power imbalance (both perceived and measured) between a dominant area and the rest of the country is a major catalyst in the formation of local identities throughout Europe. Moreover, the social significance of the center-periphery dynamics can be identified not only at the national level but also, recursively, at 'lower' levels, within regions of the nation, and even within cities and even smaller local entities.

(cf. Eckert, 2011; Gal \& Irvine, 1995) (Wang et al., 2014: 36-37)

What is of interest here is the point about the recursive scaling of center-periphery relations. In the present paper we will be looking at the playing out of center/ periphery relations in an interpreting and advocacy encounter in a Northern European city, where precarity (Standing, 2011) and poverty as we shall see, coexist with prosperity, center with periphery. 
In the past few decades, however, the construct of center/periphery originally informed by somewhat monolithic political theories which assume the persistence of "center" dominance in the world order, assisted by teleological assumptions about development, modernity and progress, has come under scrutiny and critique from theorists and activists speaking from the margins who don't entirely buy the package, while recognizing the persistent inequality in power and the distribution of goods of all sorts which is woven into the texture of societies, social life and daily living. An example of this is Trinh Minh-Ha who argues that:

The center itself is marginal...how is it possible to undertake a process of decentralization without being aware of the margins within the center and the centers within the margin? Without encountering marginalization both from the ruling center and the established margin?

(Minh-ha, 1991: 18)

Trinh Minh Ha starts to play this out from her own experience, for after all experience and subjectivity is one of the things excluded from the unfolding of "objective" political theory:

Wherever she goes she is asked for her identity papers. What side does she speak up for? Where does she belong (politically, economically)? Where does she place her loyalty (sexually, ethically, professionally)? Should she be met at the center, where they invite her with much display, it is often only to be reminded that she holds the permanent position of a 'foreign worker', 'a migrant', or 'a temporary sojourner'- a status whose definable location is necessary to the maintenance of a central power.

(Minh-ha, 1991: 18)

From this point of view power is more complex, distributed, than is allowed for in more monolithic versions of political theory. In particular, margins and peripheries have agency and can speak back, and are not being simply in waiting to be given a voice by modernity. From these complex arguments, briefly mentioned here, we can extract a few important points: firstly that centers and peripheries are in dynamic relation, mutually co-producing, in a word relational. The dynamic relational character of center/periphery is a concept which is not always grasped in the sociolinguistic theory which deals with these issues. For this reason it is interesting and important to try and imagine a sociolinguistics which speaks from the periphery. Secondly center/periphery dynamics are played out at all scales, from global to regional, to national to local and as we shall see within interactional events. The teasing out of such dynamics, within interaction is the special contribution that sociolinguistics can make to what is a much larger field. Thirdly center/ periphery dynamics and the corresponding directional flows can be understood in terms of attraction (peripheral $\mathrm{A}$ is attracted towards center B) but also in terms of of repulsion, in which the manifest unjustness of power relations and distribution 
of goods, combined with reactions to various kinds of political, cultural and linguistic hegemony, provoke a strong repulsion towards the center accompanied by counter discourses, themselves potentially forming new resistant centers. These often complex attraction/repulsion relations can be seen daily in news reports on regional and geo-politics. Georgia/Russia. Hong Kong/ PRC. Who loves America? Who hates America? What we are going to try and show in this paper is how center/periphery relations are played out at a micro scale, in an interactional event involving advocacy and interpreting.

\section{Literacy events/interpreting events: Locally situated and mobile}

The interactional event involving advocacy and interpreting which will be the focus of our analysis crucially involves what Shirley Brice Heath (1982: 50) described as 'occasions in which written language is integral to the nature of participants' interactions and their interpretive processes and strategies". The advocacy and interpreting event is also therefore a literacy event, and we will refer to it interchangeably as such. It involves not just selections of mode (spoken and written) but also selections of register. Additionally it involves working across a number of languages, so the interaction spoken and written is potentially multilingual. The notion of the literacy event implies a situated approach to literacy, but it also involves mobility: what Kell (2017) has characterized as "the travelling and circulating texts of migrants and refugees" and a focus on "the day-to-day literacy and translanguaging practices in the lives of migrants and refugees". According to Kell and others, communicative practices in a mobile world are necessarily transcontextual. So in this paper we look at literacy/interpreting activity within the frame of what Blommaert (2014) calls "a sociolinguistics of mobility", where not only humans are mobile, but also texts. The data we examine here will have something to say about texts on the move and their direction of travel as well as the influence of indexical orders, interactional regimes and their attraction/repulsion effects, as participants are both pulled towards and resist the attraction of centers, understood as hierarchically ordered interactional regimes with accompanying indexical orders.

The routine interactional events which we collected in our fieldwork tended to involve some aspect of the U.K. system, whether benefits, education or housing. The texts that were painstakingly constructed in the interpreting and advocacy sessions we observed were mobile, intended to travel to the relevant government departments. So the orientation was towards a text produced in English as an end product. In the case that we examine here the orientation is more complex, both transnational and transcontextual, involving a letter to be sent in Czech to 
the Czech Republic, though requiring validation, in English, by a U.K. lawyer. So, interestingly, two centers are in play here: the legal system and bureaucratic practices of the Czech Republic and the U.K. legal and bureaucratic system. The notion of center/periphery can help us to make sense of the hierarchically ordered interactional regimes that emerge during the interaction, firstly between standard written Czech and a non-standard Slovak influenced Czech and later on between standard Czech and English. So if the analytical frame involves an interpreted and mediated literacy event, aimed at the production of a mobile text, how can we understand the interaction in linguistic terms?

\section{Translanguaging as constitutive of the interpreting and advocacy event}

In earlier work on this topic (Baynham, 1993; Baynham and Lobanga Masing 2001) I used the theoretical construct of switching to capture not just code-switching at the level of discrete languages, but also mode-switching and register-switching: mode-switching across spoken and written modes and register - switching, for example between technical and everyday registers, when explaining some legal term to a lay person for example. In this paper we will use the more recent framework of translanguaging (Garcia \& Li Wei, 2014) to account for the linguistic interactions in this event. We see translanguaging not as an alternative, supplanting the more established term code-switching, but rather as a complementary perspective which emphasizes not the language varieties that are brought together but rather the multilingual repertoire from which the speaker or writer selects from available linguistic resources. So code-switching as a construct emphasizes the discrete nature of the component varieties, English and Czech for example, while translanguaging emphasizes how they are brought together in the repertoire. Typically studies of translanguaging to date have considered repertoire at the level of languages, hence for example English/Slovak/Czech translanguaging.

However it soon became apparent in the data for the TLANG project as a whole, that translanguaging as a construct could encompass a wider range of repertoire than simply languages. Translanguaging could involve different semiotic modes, such as visual/verbal. It could involve variety within languages, such as register, for example when a technical expression is glossed in everyday language. We have adapted Jakobson's classic distinction of interlingual, intralingual and intersemiotic translation (Jakobson, 1959) to cover these different types of translanguaging. Thus interlingual translanguaging involves discrete languages (i.e. English/ Czech/ Slovak), intralingual translanguaging involves registers (i.e. technical/everyday) and intersemiotic translanguaging involves modes (i.e. verbal/visual). 
Additionally, translanguaging theory to date has typically not addressed issues of inequality between language varieties, expressed in terms of power relations and accompanying language ideologies. It is a truism of sociolinguistics that not all language varieties in a given context are equal or at least equally regarded. To address this it is necessary to consider, as Blommaert et al. (2005) have suggested, the interactional regimes or orders which contextually position language varieties and their speakers. It is through the notion of interactional regimes that we can understand how center/periphery relations are played out in particular contexts. As Blommaert et al. (2005 et al.: 206) put it: "in the neighborhood we investigate patterns of interaction are closely tied to spatial and scalar dimensions in the organization of multilingual repertoires".

It is through investigation of these spatial and scalar dimensions and the interactional regimes that embody them, that center/periphery relations become apparent in interaction. In the two halves of the data we consider we shall consider first the interactional positioning of a non-standard Slovak influenced Czech variety, which itself can be understood in terms of translanguaging, in relation to standard written Czech. Subsequently we will examine the interactional positioning of Standard Czech in relation to Standard English, emphasizing throughout how this interactional positioning is locally occasioned.

\section{Contextualizing the interactional event}

The interactional event we will use for our discussion of the center/periphery dynamic took place at advocacy drop-in sessions provided by a charity in one of the major cities in Northern England. The charity is located in a highly diverse neighbourhood in the city, with a significant number of recently arrived migrants from Central and Eastern Europe, often of Roma ethnicity. These recently arrived migrants survive in conditions of extreme precarity (Standing, 2011) a product of neo-liberal reconfigurations of the labour market as described in Gilbert (2004) and Harvey (2005). The drop-in sessions had been set up to address specifically the needs of the Roma community, often struggling to find their way through the maze of the British bureaucratic system, such as benefits for those who are regularly dipping below the poverty level. Many of these people are still in the process of acquiring English, therefore a Czech-speaking interpreter is provided at these sessions to assist the advocate.

At one of these sessions the client, Mr Tancoš, brought in a hand-written letter for the Czech authorities, which he needed to translate into English in order to be verified by a British solicitor and sent to the Czech Republic. This was a rather atypical case in our data, since the vast majority of cases considered were 
connected with the UK benefits system, children's education, etc. However this case raised interesting issues which are discussed here.

Due to the complexity of the case, the Mr Tancoš was attended by the charity manager Rahim rather than one of the volunteer advisors. Rahim was assisted by Klára, a Czech interpreter. Also present at the session was the TLANG researcher Jolana.

Mr Tancoš was a man in his early 40s, of Roma ethnicity. He was working for a Polish construction company. Mr Tancoš was finding himself in a difficult position - he needed to send a Power of Attorney letter to his cousin in the Czech Republic in order to collect documentation related to his driving licence which he needed in his job, but at the same time he was putting himself at risk of not being offered more work by his employer for taking time off to attend the session: 'If you don't come, he's got other ten people, 'Mr Tancoš said to us, revealing the precarity of his work situation, a precarity we found to be pervasive in the lives of all those we encountered in our fieldwork.

Like so many of the people we met and engaged with in the course of our fieldwork, Mr Tancoš had been exposed to a great variety of languages in his life. He was born in Slovakia but spent a significant part of his life working in the Czech Republic, where he learnt Czech. Since his arrival in the UK, Mr Tancoš has been in contact with the English language, but also Polish, the language of his employer. He also mentioned to us that his wife spoke Russian. Despite the undeniable advantages of his language flexibility in his personal life and at the workplace, Mr Tancoš admitted that being exposed to so many languages was also a source of confusion for him and that it was not helpful in acquiring another language, in this case English:

T: a já, já si to ted’ pletu hodně, aj polsky, slovensky, česky prostě, pak to je rusky už (...) a anglicky se nemůžu naučit

T: and I, I get confused a lot now, also Polish, Slovak, Czech, then also Russian (...) and English I struggle to learn

Mr Tancoš and Klára communicated in Czech during the session, however, $\mathrm{Mr}$ Tancošs Czech was very specific. One of its characteristics was incorporation of Slovak language structures (vocabulary, case endings) as well as creation of new words, blending elements of Czech and Slovak (proukaz; sesternice). This practice of drawing on resources from different discrete languages can be described as interlingual translanguaging and in case of Mr Tancoš it was happening across at least 4 different languages - Czech, Slovak, Polish and English. This, however, did not impede a smooth communication between Mr Tancoš on one side and Klára and Jolana, who are native Czech speakers but familiar with the Slovak 
language. On one occasion, however, Mr Tancoš used a Polish word belonging to his repertoire but not recognized by Jolana. Mr Tancoš resolved the situation by rephrasing the meaning into Czech:

J hm, hm, hm, hm.... no a kde pracujete? J hm hm hm hm... and where do you work?

$\mathrm{T}$ dělám remonty $T$ I do remonts [a Polish word meaning 'refurbishments']

J co děláte? J you do what?

$\mathrm{T}$ Opravuju baráky T I reconstruct houses

We should also mention that the language of Mr Tancoš contained some of the features characteristic of what has been termed the Romani ethnolect of the Czech language (Bořkovcová, 2006), a dialect spoken by some Czech Roma as a result of a contact (direct or indirect) with the Romani language. The Romani ethnolect of the Czech language is characterized by the transposition of phonetic, grammatical and lexical structures of Romani and Eastern Slovakian dialects into Czech. In Mr Tancošs case, these features were mostly of a phonetic nature and included vowel shortening and placing the stress on other than the first syllable, which is the normal position for stress in both Czech and Slovak languages.

In the context of an informal conversation between Mr Tancoš and Klára, the varieties of their spoken language coexist side by side and do not obviously enter into a center/periphery hierarchy. This situation changes in the moment when they turn their attention to Mr Tancošs hand-written draft of the Power of Attorney letter. This contextual change means a move across modes (from spoken to written) as well as across registers (from informal to formal).

Klára is struggling with some of the formulations in the handwritten draft, stemming from Mr Tancošs lack of familiarity with Czech legal terminology. Some of the words appear misspelled; on some occasions Mr Tancoš creates a word which sounds similar to the legal term he has in mind, but with a completely different meaning. That is the case of 'power of attorney' - 'plná moc' in Czech. $\mathrm{Mr}$ Tancoš merged the two words into one, which Klára reads out as 'půlnoc' (meaning 'midnight' in Czech):

$\mathrm{K}$ co to je tady napsaný, půlnoc? $\mathrm{K}$ what is it written here, půlnoc? [midnight]

T: pulnomoc, no, sem to nadepsal asi, ja už tu gramatiku... T pulnomoc, yea, I've titled it, perhaps, my grammar...

Mr Tancoš is aware of his limited capability to produce a grammatically correct text and agreed to Klára's suggestion to rewrite the letter. In this situation as we shall see, Klára's standard Czech becomes the center, treated interactionally 
as hierarchically superior to Mr Tancošs language which contains elements of different languages and non-standard neologisms. Klára however uses her excellent interpersonal skills to avoid the situation being interpreted in this light, carefully formulating her reasons for rewriting the letter and even using inclusive 1st person plural ('we want') in ways that mask the power dynamic and serve to diminish the gap between their language competencies and to avoid a possible negative reaction from Mr Tancoš. Her effort is rewarded by Mr Tancošs acknowledgement of the situation in which his version of the letter is positioned on the periphery in relation to Klára’s "correct" Czech:

\section{$\mathrm{K}$ já teda... když už to teda chcete česky K I well... since you want it in Czech $\mathrm{T}$ já vám věrim $T$ I trust you \\ K ((laughs)) jo? Já (.) mého (.) řidičs- (.) tečky, když už to chceme správně $K$ ((laughs)) yea? I (.) my (.) drivi-(.) accents, since we want it correct...}

Klára and Mr Tancoš also have different perspectives on what language is acceptable for the Czech authorities - whereas Mr Tancoš believes that using Czech alongside Slovak in his letter, thus effectively translanguaging, 'won't be a problem', Klára's view on the exigencies of Czech bureaucratic institutions is different: 'cause in Czech they are very strict when it comes to stuff like that, it needs to be very precise.' Although Klára gives Mr Tancoš voice to express his opinion in the process of rewriting the letter, and on occasions he argues for his version quite forcefully, it is her formulation that eventually wins.

Once the letter is ready, the next step is producing a version in English to be taken to the British solicitor. This process is led by Rahim, who is familiar with legal language and procedures. Klára reads out the letter she's just produced with Mr Tancoš, translating it into English and Rahim is typing up the new letter, which he is simultaneously rephrasing to match the British bureaucratic requirements. The letter therefore undergoes changes on several levels - apart from moving across languages (from Czech to English), there is a change across registers - from standardly formal in Czech to legal in English.

Klára in this process finds herself in an analogous position to Mr Tancoš, when she was rewriting his letter. The center of the interaction shifts from the letter produced by Klára to the new letter that is now being composed by Rahim, designed to meet the requirements of British, not Czech or Slovak institutions. Once Rahim has composed the new letter, he then asks Klára to translate his letter back into Czech. At first, she is reluctant to do so, not so much because she would be questioning Rahim's knowledge of the correct procedure, but because she fails to see the difference between the registers of the two letters and thinks that translating the letter back into Czech is a redundant step. We can again interpret this 
hesitation as a resistance against what would mean in effect moving her original letter to the periphery. After she has a closer look at Rahim's letter, however, she realizes the difference between the registers and she is prepared to proceed.

Once this new version of the Czech letter is ready, Mr Tancoš is free to go to the solicitor on the same street. He is taking with him the letter in legal English produced by Rahim as well as the third version of the Czech letter, which has undergone a transformation from a draft by Mr Tancoš in a non-standard Slovakinfluenced Czech language to a version composed by Klára in formal Czech to the final version, which is a translation of Rahim's letter, produced to meet the British bureaucratic standards.

The exhausted Klára jokes about the whole process, which took almost an hour and a half instead of a previously expected 20-minute session, saying to $\mathrm{Mr}$ Tancoš: If they don't accept this then I don't know what they will! She gives him back his original letter - which he takes back, laughing - and then scrunches up her own previous versions of the letter (now redundant) and throws them away indexing their eventual worthlessness.

\section{Interactional regimes in the interpreting event}

As we saw in the previous section, the interactional event falls into two distinct parts. In the first a letter, handwritten by Mr Tancoš in non-standard Slovak influenced Czech, is transposed by Klára with the help of Jolana into standard Czech, in a register deemed by Klára and Jolana appropriate for communication with a government department. As the standard version of the letter is composed, there are repeated tensions as $\mathrm{Mr}$ Tancoš perhaps half-heartedly argues against Klára's revisions, while ultimately falling into line and telling her he trusts her. Standard written Czech functions as a central variety, to which $\mathrm{Mr}$ Tancošs non standard spoken-like Slovak inflected variety is peripheral. We see the power relations between these two varieties played out in the interaction between Mr Tancoš and Klára.

In the second section, the situation is reversed and the letter in Standard Czech prepared by Klára becomes raw material to be reworked by Rahim into a legal formulation in English for giving Power of Attorney. It is important to understand the power dynamics of this: Rahim is not simply translating Klára's letter into English as she assumes he will. He is using the facts as presented in the letter as raw material for an entirely new legal text, which he constructs in interaction with Klára. Here Standard Czech becomes the peripheral variety, while Standard Legal English is asserted as the central variety, in accordance with which the Power of Attorney letter must be shaped. 
The act of translation here implies a primacy or dominance of the translated text. The translating text is understood implicitly as orienting to its reproduction or reconstruction. But this is precisely what does not happen here. The legal requirements of a Power of Attorney lead Rahim to entirely re-shape the letter in the direction of what he considers to be the appropriate legal formulation. It is for this reason that Klára's letter in Standard Written Czech is not accorded the status of text-to-be-translated, but is instead treated simply as raw material providing information that can be inputted into the text that Rahim is constructing. Just as Mr Tancoš resisted at points Klára’s reformulation of his words, so does Klára express a certain amount of exasperation that her efforts with the letter will be set aside. Finally it is Rahim's text that will have to be re-translated into Czech. In the next sections we will examine the two interactional sequences in more detail, showing how in the writing and re-writing processes, high status formulations are asserted and contested by participants, demonstrating as it were interactional regimes in action.

\section{Transforming non standard Czech to standard written Czech}

The interaction starts with a discussion of how the question of obtaining a replacement driving licence in the Czech Republic had been addressed at an earlier session the week before. Mr Tancoš positions himself as following Klára’s instructions.

$\mathrm{T}$ já jsem to ještě jednou napsal jak ste mi to řikala jó všec- všechno T I wrote it once more like you've told me yea eve- everything

Klára as she reads through what he has written almost immediately starts to identify invented words and phrases and incorrect formulations, characteristic perhaps of a writer who has some familiarity with legal terminology in Standard Czech, but doesn't control it.

$\mathrm{K}$ co to je tady napsaný, půlnoc? K what is it written here, půlnoc?

$\mathrm{T}$ pulnomoc, no, sem to nadepsal asi, ja už tu gramatiku... T pulnomoc [misspelled], yea, I've titled it, perhaps, my grammar...

Klára and Mr Tancoš then go into a process of negotiating which language the letter should be drafted into.

K No protože tak ( ) vy máte i slovensky. Mám to napsat celý česky? $K$ well because so () you have it in Slovak as well. Should I write it all in Czech?

$\mathrm{T}$ ( ) napište () T () write () 
$\mathrm{K}$ protože tam máte česky i slovensky $K$ because you have it in Czech and also Slovak

$\mathrm{T} \quad()$

K ((to Rahim)) you know why, because it's written Czech and in, not Czech, Czech and Slovak, there are mixed words

$\mathrm{T}$ já si myslim že to nebude problém $T$ I think it won't be a problem

$\mathrm{K}$ ((to Rahim)) and I said do you want it Czech or Slovak, he said Czech but like

$\mathrm{T}$ já si myslim že to $T$ I think it

$\mathrm{K}$ ((to Jolana)) 'preukazu' is Slovak, isn't it?

J hm

$\mathrm{T}$ já si myslim že to nebude problém oni si tam přečtou $T$ I think it won't be a problem they will read it

Klára's view seems to be that the letter should be written in Standard Czech. $\mathrm{Mr}$ Tancoš on the other hand seems to be thinking, what does it matter, they will understand it. The whole interaction takes place in a framing context where $\mathrm{Mr}$ Tancoš states he is taking Klára's advice and trusts her, but this doesn't stop him questioning her advice and suggestions on a number of occasions, all with a similar dynamic. Klára suggests a "correct" formulation in Standard Czech, while $\mathrm{Mr}$ Tancoš responds with a what does it matter, they will understand position.

In the following extract, the dispute, which is low key but persistent, rests on how the person to whom power of attorney is to be given. Mr Tancošs cousin Antonia should be referred to. Klára prefers "paní" (= Mrs) signalling a politer more formal letter writing style, while Mr Tancoš again prefers his simpler version:

$\mathrm{T}$ to tam nemusí být ta sestrnice já si myslim $T$ that doesn't have to be there that cousin I think

J né chcete ji vyškrtnout? J no do you want to cross her out?

$\mathrm{K}$ ale aby věděli jak to (.) né? K but for them to know how it (.) no?

$\mathrm{T}$ stačí dávám plnou moc T just I give the power of attorney

K nebo paní? Mé K or Mrs? my

$\mathrm{T}$ dávám pulnomoc Antonii Tancošové a hotovo T I give the power of attorney to Antonia Tancošová and that's it

$\mathrm{K}$ jo? K yea?

$\mathrm{T}$ nó já si myslim $T$ yea I think

K paní paní jo? Paní Antonii K Mrs Mrs yea? To Mrs Antonia

$\mathrm{T}$ nemusí být ani paní prostě $T$ you don't need even Mrs

$\mathrm{K}$ ale tak (.) je to lepší (.) paní (.) paní paní K but (.) it’s better (.) Mrs Mrs Mrs

Again what Klára is asserting is the register of letter writing in Standard Written Czech, formality here signalled by a term of address, while Mr Tancoš is preferring 
the simpler unadorned form. Klára's version wins out which is why we can say that there is an interactional regime in operation which positions the formal register of Standard Written Czech as central and Mr Tancošs informal, non standard variety, incorporating elements of Slovak/Czech translanguaging, as peripheral. Klára here is voicing the standard position, shifting the letter towards her sense of how an appropriate letter should be written, articulating implicitly a language ideology about register, formality and correctness in this type of correspondence. Mr Tancoš on the other hand voices a resistant counter position, which can be expressed as "What does it matter? They'll understand anyway", within which again a language ideology can be discerned, which could be formulate as "Don't worry about form, what is important is getting the meaning across". Here $\mathrm{Mr}$ Tancoš is expressing, albeit rather mildly, resistance/repulsion in relation to the attraction factor of the center.

\section{Translanguaging, interactional regimes and language ideologies}

So what role does translanguaging play in this interaction? There is clearly a great deal of interlingual translanguaging going on, with the languages in play being Czech, Slovak and English. There is also in the interaction around the construction of the revised and corrected version of Mr Tancošs letter considerable intralingual translanguaging going on, in the shifting of Mr Tancošs original formulations towards the forms and register of Standard Written Czech. Given the nature of the variety in which Mr Tancoš is writing and speaking, which involves both features of Czech and Slovak as well as the informal rather than formal register features, we can say that there is a mixing and blending of both interlingual and interlingual characteristics in the translanguaging we analyse, particularly in the speech and writing of Mr Tancoš. Again, if we look at the work that Klára is doing in reformulating and rewriting Mr Tancošs original letter we notice that her interventions are all in the direction both of less translanguaging and conformity with certain standard language and register norms, such are typically associated with formal letter writing, and not of course just in Czech.

If we look back at what Klára and Mr Tancoš expressed during the drafting process, trying to understand the implicit language ideologies involved, we find that Klára's interventions are all in the direction of standardized norms, away from mixing and blending of languages (Czech and Slovak) and registers (formal/informal). The language ideology that Klára seems to express in this context is keep separate, conform to the norms of a particular standard written language. This involves a move away from the kind of translanguaging evident in Mr Tancošs speech and writing, which draws on both Czech and Slovak, informal and spoken-like 
formulations, as well as misheard or misunderstood legal terms. So there is a process of "normalizing" of Mr Tancošs text, understood as making it conform to the norms of Standard Spoken Czech. What is important to understand is that this normalizing is an ironing out of the features we might describe as translanguaging. On the other hand we can now expand the language ideology that is expressed in $\mathrm{Mr}$ Tancošs resistant contributions as supporting the characteristics of translanguaging as a way of making meaning: "don't worry, they'll understand".

This enables us to reach two interesting observations about translanguaging: firstly that it is always influenced and shaped by the power relations between language varieties in this case Standard Czech and a non standard Slovak influenced Czech variety, secondly that translanguaging itself appears to be typically what Pennycook and Otsuji (2015) call "language from below" or from the periphery. Centers normatively control and regulate language use, as it were embordering language, maintaining distinctions between language varieties and registers including the distinctions created by terms of address. In contrast, the alternative, translanguaging ideology as expressed by Mr Tancoš in resisting the shifts in the text proposed by Klára emphasises meaning making across the repertoire. This also points up a characteristic that we think is interesting about translanguaging, is that it slips out of the normative regulation of centers, here involving how to write an effective formal letter with legal status and is thus a subversion of these norms. When he says "don't worry, they'll understand" he is effectively cutting through or rather proposing to cut through the complex tissue of norms, values and language ideologies that constitute a standard language.

It is important in considering this argument to consider the distorting effect of theory. The interaction analysed is friendly, polite and respectful. Mr Tancošs dissent is quite low key. He doesn’t protest when Klára ignores his suggestions. They are expressed within a frame in which he professes himself happy to yield to her judgement. Nevertheless we have been able to show that there are two quite clearly expressed language ideological positions expressed as to how the letter should go and that one of them carries the day. We suggested above that center periphery relations can of course be characterized by attraction, but also by rejection/repulsion. Klára, an educated professional, draws on the norms, values and ideologies of embordered standard language in order to redraft the letter into a form she thinks will be more likely to be effective. Mr Tancoš is resisting these norms and values, proposing what could be described as a translanguaging ideology, drawing on the linguistic repertoire he has available and assuming he will be understood.

We think that understanding translanguaging as speaking from below or from the margin/periphery is important, as is seeing its role in providing a counter discourse to the norms, values and ideologies of standardized languages. It is also important to be aware that translanguaging always involves relations of power. 
The equation underlying the position that Klára implicitly takes up in this interaction is that a letter that conforms to the norms and values of standard language will be more effective than one that doesn't. Mr Tancoš takes another position which involves stripping off the differentiation that is involved in drafting the letter in a particular register. His position rests on what will be understood without the complex signalling of social difference implicit in complex high status registers.

In this analysis we have shown how a non standard Slovak influenced variety of Czech is positioned as marginal in relation to a standard written variety of Czech in the first part of this interpreting and literacy event. We have also seen how translanguaging is more characteristic of the marginal variety and the interactions involved in rewriting Mr Tancošs draft are to be understood in terms of ironing out the translanguaging and shifting towards a monovarietal norm: standard written Czech. This is the interactional regime that positions the varieties as well as their speakers/writers. We can further conclude that there is some kind of relation between what is socially dominant and monovarietal norms, values and ideologies. In contrast $\mathrm{Mr}$ Tancošs resistant stance in the rewriting asserts another kind of language ideology. It is the aim of this paper to argue that such center/peripheral relations are precisely relational, shifting and changing according to context and circumstances.

\section{Re-casting the power of attorney letter in English}

The second phase of the session involves Rahim who is the manager of the charity where the drop-in sessions take place. In order to lodge his application in the Czech Republic, Mr Tancoš needs legal confirmation in the form of a sworn statement that he did indeed write the letter authorizing his cousin to have power of attorney. As this is beyond the competence of Klára they are waiting for Rahim to return. Klára talks to the volunteer advisor Carol, temporarily present in the room, summarizing to her the course of the session. Jolana and Angela from the TLANG project also joins in the discussion.

K ( ) so what he wants to do erm so he wrote this letter yea to give to his sister and his sister will go with this letter it's to give her permission that she can go on his behalf to this office and they would give her what he needs

$C$ in in Czech

$\mathrm{K}$ in the Czech Republic. Yea. She live in the Czech Republic. It's not his sister it's his cousin. So but yo- anyone can write letter like that. Yea so his sister could write his cousin can write a letter like that so what he needs a proof that erm they want to see that it was him who wrote it yea so it's a it's a kind of stamp

C hm

$\mathrm{K}$ which he needs from solicitor like a power of attorney stamp 
C hm

$\mathrm{K}$ that he's giving permission to his cousin to do that. So what Rahim said he said he can give something called sworn statement I don't know how he gives that I don't know how he does that

C yea

$\mathrm{K}$ does he by stamp or by letter I don't know

C I don't know ( ) ((laughs))

$\mathrm{K}$ but he said he will come back to do that

C yea

K I don't know it's new to me so he will do ((laughs)) he will come back and he said he said he will come back in ten minutes to do that and erm we will see ((laughs)) what how this sworn statement looks like yea and with that

A it's just a stamp probably it's just a stamp I would guess

$\mathrm{K}$ yea

$\mathrm{J} \quad \mathrm{hm}$

$\mathrm{K}$ so (.) and he will only give the stamp once the letter is translated to say yes whatever he he wrote in the letter is what he wrote in the letter

C uhm

$\mathrm{K}$ yea? because anything can be written in Czech if you don't understand it

Rahim arrives and there is an interlude when he completes a registration form for Mr Tancoš as this was his first time to attend the drop-in sessions. Then Klára explains to Mr Tancoš what Rahim will do:

$\mathrm{K}$ ((sighs)) he's asking what what you're going to do with this letter

R I'm going to write it in English and then I'm going to ask him to go to the solicitor he'll have to pay five pounds and then he will stamp it and sign it

$\mathrm{K}$ all right ok. Pán Vám napíše tohle anglicky přesně to co jste napsal tady jo napiše dopis $\mathrm{k}$ tomu že to je pravdivej překlad vy půjdete vedle vedle $\mathrm{k}$ právníkům tam zaplatíte pět liber $K$ all right ok. The gentleman will write this in English exactly what you wrote here yea he will write a letter to go with it that it is a true translation you will go next door to the lawyers you will pay five pounds there

$\mathrm{T}$ takže měl jsem pravdu T so I was right

$\mathrm{K}$ uhm-uhm, dá Vám razítko a hotovo $\mathrm{K}$ uhm-uhm, he'll give you a stamp and done

$\mathrm{T}$ děkuju mockrát $\mathrm{T}$ thank you very much

There is quite an extended interaction in which Rahim and Klára and others work to establish how the letter giving power of attorney to Mr Tancošs cousin in order to obtain the documentation for his driving licence is to be produced and then stamped by a lawyer to confirm that it is a true statement by Mr Tancoš. Rahim then 
proceeds to start drafting the letter in English, drawing both on the Standard Czech version that Klára has just produced and on further oral questioning that Klára interprets. What he is doing, as will become apparent when he reads it back, is not simply translating, but re-casting the letter into the correct legal format for a sworn statement. As a consequence the text he finally produces is not an exact translation of Klára’s Czech "original" but actually a new text, produced in conformity with UK legal requirements. Once completed, Rahim reads the English text back:

R ok so what I've written here erm oh ( ) I say this is sworn statement of Milan Tancoš yea

K uhm-uhm

R I Milan Tancoš of 25 Ashley Road Leeds LS8 1DE UK date of birth tenth November nineteen sixty-six personal ID number 7250205568 make oath and say as follows I confirm that I Milan Tancoš give power of attorney to Mrs Anto- Ant- what is it Antonia

$\mathrm{K}$ erm yea yea

$\mathrm{R}$ yea

$\mathrm{K}$ Antonia, yea

$\mathrm{R}$ yea date of birth twentieth August nineteen seventy-three address as he's mentioned Czech erm and Czech Republic to collect my driving license documentation

$\mathrm{K}$ tak vlastně von tam napsal přesně to co sme napsali tady že ale že přísaháte jo že prísaháte že tadyty že $K$ so in fact he wrote there exactly what we wrote here, that, but that you swear, yea, that you swear that these, that

$\mathrm{T}$ jo jo jo T yea yea yea

$\mathrm{K}$ takle to je, ale to to je jediný co tam dodal $\mathrm{K}$ it's like this, but that that's the only thing he's added there

$\mathrm{T}$ jo $T$ yea

$\mathrm{K}$ a pak tam napsal přesně stejný informace $K$ and then he wrote there exactly the same information

$\mathrm{T}$ jo $T$ yea

$\mathrm{K}$ co ted'ka K he has just

$\mathrm{T}$ jo $T$ yea

$\mathrm{K}$ čet. Jo? K read. Yea?

Rahim then goes on to explain what Mr Tancoš must do to get the sworn statement witnessed by a lawyer. In the final stage of the interaction Rahim explains that Klára is required to translate this new legal text back into Czech. In the interaction that follows, a misunderstanding becomes apparent which highlights the conflicting interactional regimes at play. When Rahim asks her to translate the 
new English text into Czech, Klára is puzzled. As far as she is concerned the text already exists in Czech, so why re-translate it? Rahim points out that the English text has been written to satisfy the legal requirements of a sworn statement and needs to be re-translated back into Czech to satisfy these requirements. What is at issue here is the fundamental interactional dynamics of the translation exchange: that the original is the authoritative text which must be rendered into the language of translation. As Rahim insists, the English text has in effect become the authoritative original which must be rendered into Czech.

$\mathrm{R}$ ok now what he needs to do erm no could you do the same thing on a on a piece of letter for him because this is a different format now this is like a proper sworn statement it's like a legal document kind of

$\mathrm{K}$ just to write exactly the same thing in English

$\mathrm{R}$ yeah

$\mathrm{K}$ all right that's fine

$\mathrm{R}$ in in Czech

$\mathrm{K}$ in Czech?

$\mathrm{R}$ yea

$\mathrm{K}$ in there?

$\mathrm{R}$ no no in on the paper there

$\mathrm{K}$ oh

$\mathrm{R}$ then he

K ( )

$\mathrm{R}$ then the solicitor can sign that one and then I'll tell you what to write underneath it

$\mathrm{K}$ oh in Czech ( )

$\mathrm{R}$ yeah

K but it's oh sorry I don't understand why because ((starts laughing))

$\mathrm{R}$ no no because this

$\mathrm{K}$ yeah

$\mathrm{R}$ is written

$\mathrm{K}$ yeah

$\mathrm{R}$ in Czech

$\mathrm{K}$ yea yea

$\mathrm{R}$ but the format is different

$\mathrm{K}$ yes

$\mathrm{R}$ ok this is like a legal thing this is

$\mathrm{K}$ yeah

$\mathrm{R}$ what he's written here

$\mathrm{K}$ yeah 
$\mathrm{R}$ so if we change it this one to that one it will look more erm

$\mathrm{K}$ all right so to write this in Czech

$\mathrm{R}$ first of all sworn statement of

$\mathrm{K}$ this statement this statement

$\mathrm{R}$ yea yea

$\mathrm{K}$ in Czech

$\mathrm{R}$ yeah

$\mathrm{K}$ in here

$\mathrm{R}$ yes

$\mathrm{K}$ ah

$\mathrm{R}$ is that ok

$\mathrm{K}$ yea on this different paper

$\mathrm{R}$ I'll I'll get you another paper

$\mathrm{K}$ ok ((laughs))

J hm

K I wasn't sure what he wanted

Klára seems rather bemused and irritated by the long windedness of this process, but also aware that she has wasted time in producing the text prematurely in Czech, since the "original" text now needs to be produced in English.

This final stage of re-translation poses problems for finding translation equivalents, similar to that of finding a translation for the Czech term "register" in the first phase. Klára and Jolana struggle, perhaps resistantly, with how to translate "Sworn statement" into Czech:

J takže Rahim to napsal vlastně tak jak by to mělo bejt eště tam přidal ňáký další takový ty fráze a (.) budeš tam psát i to $J$ so Rahim actually wrote it the way it should be he added some of those phrases and (.) are you going to write there also that

$\mathrm{K}$ co K what

J to sworn statement? To uplně nahoře? J that sworn statement? That at the very top?

$\mathrm{K}$ rodné číslo já sem si řikala jak bys to přeložila? Já bych dala jakože přís- erm že př́saháš jako př́saha? K personal number I was thinking how would you translate it? I would put like sw-erm that you swear like a sworn statement?

J př́saha J sworn statement

$\mathrm{K}$ taky řikala, př́saha pana $K$ was also thinking, sworn statement of $\mathrm{Mr}$

J já jsem ( ) $J I()$

K Milan Tancoš? K Milan Tancoš?

$\mathrm{J} \mathrm{hm}$ hm čestné prohlášení $\mathrm{J} \mathrm{hm} \mathrm{hm} \mathrm{sworn} \mathrm{statement}$

$\mathrm{K}$ nebo čestné prohlášení K or sworn statement

J čestný prohlášení J sworn statement 
$\mathrm{K}$ no ale $\mathrm{v}$ tom prípadě $K$ yea but in that case

$\mathrm{T}$ přehlasuju že to co sem napsal T I swear [wrong word formation] that what I have written

$\mathrm{K}$ jak by si ale to sem právě myslela čestné prohlášení tady make oath and say nebo prís- K but how would you that's what I was thinking sworn statement here make oath and say or sw-

J ( )

K make oath

$\mathrm{J}$ ((reading in low voice in the background))

$\mathrm{K}$ and say as follows

$\mathrm{J} \quad$ ((reading in low voice in the background))

$\mathrm{J}$ make oath and say

K ( )

J př́sahám a a prohlašuji I I swear and and declare

$\mathrm{K}$ př́sahám a prohlašuji a tady čestné $K$ I swear and and declare and here sworn

J čestné prohlášení J sworn statement

K prohlášení. Jó? Takže ne jo tak čestné no máš pravdu to je asi zní líp než prísaha vid' K statement. Yea? So no yea so sworn well you are right that perhaps sounds better than oath, right

\section{Competing interactional regimes: The relationality of center/periphery}

What we find in this extended exchange is a reversal of the interactional regime in the first phase, in which Klára transformed Mr Tancošs original text with its errors and mixing of Czech and Slovak into a standard written Czech format. This format Klára judged would be most appropriate in addressing the Czech authorities who needed to provide the documentation $\mathrm{Mr}$ Tancoš required. In the early stage of the second phase Klára appears to think that what is required is a translation of the Czech "original" into English. However it soon becomes apparent that the legal requirements of the sworn statement require a re-casting of the information contained in the Czech "original" combined with additional information gleaned through oral questioning of Mr Tancoš, interpreted by Klára. So rather than being the privileged "original" to be faithfully translated into English, the Czech letter becomes simply a source among others for constructing the appropriate legally framed English text. What went wrong?

In the first phase it seems that Klára and others present are orienting to the requirements of the Czech authorities. The interactional regime which is produced, positions Klára’s Standard Written Czech version as central and Mr Tancošs Slovak inflected Czech variety combined with lexical and grammatical errors on the margin. Mr Tancoš resists this re-working at times, asserting as we have suggested above, 
another language ideology based on getting your meaning across, rather than formality, correctness and appropriacy. So we can say that interactional regimes are based on relations of power, ultimately in this case the power of the relevant Czech authorities to regulate and control who is licensed to drive a car.

In the second phase, the material in Czech, both spoken and written, becomes positioned as peripheral or marginal in relation to another center of power and accompanying interactional order, the British legal system with its sedimented requirements on how to phrase a sworn statement. Rather than being the privileged "original" to be translated into English, the Czech text becomes simply source material in the construction of the English text. This point is made clear when it becomes apparent that the English text now has to be translated back into Czech.

\section{Direction of travel: Mobile subjects/mobile texts}

This data also allows us to say something about the direction of travel of mobile subjects and mobile texts, along the lines proposed by Kell (2017). Mr Tancoš arrives with a text that is already, as he points out, a consequence of taking advice from Klára about how to phrase the letter. However Klára continues to push his version towards Standard, bureaucratically appropriate Czech. The hierarchically ordered interactional regime is here Standard Czech (central)/ non Standard Slovak Czech (peripheral). It is worth mentioning in connecting such interactional regimes to indexical orders that indexicality itself is a temporal/spatial metaphor, a pointing out from here to there. We see attraction/repulsion effects in operation as Mr Tancoš, Klára and Jolana negotiate the revised letter in Standard Czech. The overall direction of travel, however, is towards Standard Czech. In the second phase of the interaction, when a new hierarchically ordered interactional regimecomes into play, that of legal English, the painstakingly worked on text in Standard Czech becomes simply raw material for the working up of a new text in English which then, to Klára’s irritation, has to be translated back into Czech. Here the text trajectory, its direction of travel, is from Czech to English and back again. What the dimension of attraction/repulsion enables is a way of thinking about the affective aspect of subject/text mobility which is potentially relevant to transcontextual analysis more generally.

\section{Conclusion}

We have seen how in the first phase standard Czech is the privileged other in relation to Mr Tancošs variety, and how in the second phase English becomes the privileged other in relation to standard Czech. What does this imply for our understanding of center/periphery relations discussed at the beginning of the paper? 
Firstly we have seen how the interactional regimes and center/periphery relations change depending on whether the interaction is oriented towards the requirements of the Czech or UK system. Within the Czech system Mr Tancošs non standard variety combined with grammatical, lexical and register "errors" is positioned as peripheral in relation to standard written Czech. However we have also noted that $\mathrm{Mr}$ Tancošs variety is characterized by Czech/Slovak translanguaging as well as register variation (attempts at formal legal register/everyday language) and that the work that Klára does to transform his non standard translanguaging Czech into standard written Czech can be undertood as a monovarietal shift. This leads us to suggest that translanguaging is typically language from below, while the effect of institutional power, creating embordered language varieties whose function is to differentiate, discriminate along a number of parameters, one of which is inclusion/exclusion.

Secondly we have seen that there is nothing intrinsic about center/periphery relations, indeed that one center can be construed as peripheral in relation to another center. This is what we see happening in the second phase of the interaction we examined. Standard Czech is central in the first phase, oriented to a Czech institutional audience, but becomes peripheral in the second, oriented towards the requirements of the British legal system. This is what we mean by saying that the center/periphery construct is relational.

By considering the dynamic, transcontextual aspect of the text production here, its direction of travel, in terms of the attraction/repulsion dynamic observed as the interaction unfolds, first in Mr Tancošs resistance to the direction proposed by Klára, then in Klára's resistance to that proposed by Rahim, we can understand something of the affective dimension of the multilingual communicative work engaged in here: both Mr Tancoš and Klára first resist and then submit to the interactional regime currently in place, acept that they are positioned as peripheral in relation to its center.

Finally this data helps us nuance the analysis of translanguaging, pointing to the need to factor into our discussions of translanguaging issues of power,interactional orders inequality, center/periphery and the ways these express and are expressed by language ideologies. This is a point powerfully made for translation studies by Lee in his Translating the Multilingual City (Lee, 2013) and it holds good for translanguaging as well.

\section{References}

Baynham, M. (1993). Code-switching and mode-switching: community interpreters and mediators of literacy. In B. Street (Ed.), Cross-cultural approaches to literacy (pp. 294-314). Cambridge: Cambridge University Press. 
Baynham, M., \& Lobanga Masing, H. (2001). Mediators and mediation in multilingual literacy practices. In M. Martin-Jones \& K. Jones (Eds.), Multilingual literacies: Comparative perspectives on research and practice. Amsterdam: John Benjamins.

Blommaert, J., Collins, J., \& Slembrouck, S. (2005). Polycentricity and interactional regimes in 'global neighborhoods'. Ethnography, 6(2), 205-235. doi:10.1177/1466138105057557

Blommaert, J. (2014). From mobility to complexity in sociolinguistic theory and method. Tilburg Papers in Culture Studies, 103.

Bořkovcová, M. (2007). Romský etnolekt češtiny [Czech Romani Ethnolect]. Prague: Signeta.

Garcia, O., \& Wei, L. (2014). Translanguaging: Language, bilingualism and education. London: Palgrave Macmillan.

Gilbert, N. (2004). Transformation of the welfare state: The silent surrender of responsibility. Oxford: Oxford University Press.

Harvey, D. (2005). Neoliberalism. Oxford: Oxford University Press.

Heath, S. B. (1982). What no bedtime story means: Narrative skills at home and school. Language in Society, 11(1), 49-76.

Jakobson, R. (1959). On linguistic aspects of translation. Reprinted in L. Venuti (ed.) (2000), The translation studies reader. London: Routledge.

Kell, C. (2017). Travelling texts: Translocal/Transnational literacies and transcontextual analysis. In S. Canagarajah (Ed.), Routledge handbook of language and migration. London: Routledge.

Lee, T-K. (2013). Translating the multilingual city: Cross-lingual practices and language ideology. Bern: Peter Lang. doi:10.3726/978-3-0353-0459-6

Pennycook, A., \& Otsuji, E. (2015). Metrolingualism: Language in the city. London: Routledge.

Standing, G. (2011). The precariat. London: Bloomsbury.

Trin Minh-ha. (1991). When the moon waxes red: Representation, gender and cultural politics. London: Routledge.

Wang, X., Spotti, M., Juffermans, K., Cornips, L., Sjaak, K., \& Blommaert, J. (2014). Globalization in the margins: Toward a re-evaluation of language and mobility. Applied Linguistics Review, 5(1), 23-44. doi:10.1515/applirev-2014-0002 